\title{
Exposure Assessment and the Risk Associated with Trihalomethane Compounds in Drinking Water, Cairo - Egypt
}

Eglal R Souaya1 ${ }^{1}$ Ali M Abdullah ${ }^{2 *}$, Gouda A RMaatook ${ }^{3}$ and Mahmoud A khabeer ${ }^{2}$

${ }^{1}$ Faculty of Science, Ain Shams University, Khalifa El-Maamon Street, Cairo, 11566, Egypt

${ }^{2}$ Holding Company for water and wastewater, IGSR, Alexandria -1125, Egypt

${ }^{3}$ Central Laboratory of Residue Analysis of Pesticides and Heavy Metals in Foods, Agricultural Research Centre, Ministry of Agriculture and Land Reclamation, Egypt

\begin{abstract}
The main objectives of the study to measure the concentrations of trihalomethanes (THMs) in drinking water of Cairo, Egypt, and their associated risks. Two hundred houses were visited and samples were collected from consumer taps water. Risks estimates based on exposures were projected by employing deterministic and probabilistic approaches. The THMs species (dibromochloromethane, bromoform, chloroform, and bromodichloromethane) ranged from not detected to $76.8 \mu \mathrm{g} / \mathrm{lit}$. Non-carcinogenic risks induced by ingestion of THMs were exceed the tolerable level $\left(10^{-6}\right)$. Data obtained in this research demonstrate that exposure to drinking water contaminants and associated risks were higher than the acceptable level.
\end{abstract}

Keywords: Drinking water; Risk; Trihalomethanes; Cairo

\section{Introduction}

Chlorination, the most commonly used method to disinfect tap water, has led to a sharp decrease in both mortality and morbidity from many diseases known to be waterborne [1]. However, the presence of chlorinated disinfection by-products (DBP) in tap water is of concern from a public health aspect because they are suspected to be carcinogenic [2-4]. The most significant group of DBP formed during chlorination is the $\mathrm{THM}$ such as $\mathrm{CHCl}_{3}, \mathrm{CHBrCl}_{2}, \mathrm{CHBr}_{2} \mathrm{Cl}$, and $\mathrm{CHBr}_{3}$. $\mathrm{CHCl}_{3}$ is classified in Group $2 \mathrm{~B}$ as a possibly carcinogenic to humans, based on limited evidence of carcinogenicity in humans but sufficient evidence of carcinogenicity in experimental animals [1]. $\mathrm{CHBrCl}_{2}$ is a weekly mutagenic and it has been classified as probably carcinogenic to humans, with sufficient evidence in animals and inadequate evidence in humans. Between the four THMs found in drinking water, $\mathrm{CHBrCl}_{2}$ appears to be the most potent rodent carcinogen. $\mathrm{CHBr}_{2} \mathrm{Cl}$ and $\mathrm{CHBr}_{3}$ are classified in group 3 due to the inconclusive genotoxicity [1]. The second prevalent DBP group is haloacetic acids (HAAs). Aside from THMs and HAAs, many other compounds that comprising the DBP group have been found in treated waters, which include haloacetonitriles, haloketones, haloaldehydes, halopicrin, cyanogen chloride, halophenols and chloral hydrate and many others. The main THM effects are cancer and adverse reproduction problems such as abortion, miscarriage, and retarded fetal development [5].

Chloroform concentrations measured in breath or blood after swimming and showering have been correlated with the activity time, and the concentration of this compound found in water and air [6]. Rafael et al. have reported that the THM concentration increases in blood as compared with their pre-activity blood levels in individuals after water-consuming [7].

They have found that increases of THM concentrations in blood after showering or bathing were significantly greater than the increases related to regular water-consuming. On the other hand, Chowdhury et al. have found that showering activity increases the THM concentration in blood, but there was no significant correlation between THM concentration in blood and tap water. The focus of this work is not directed to quantify the DBP precursors in the water treatment plant. Instead, the main motivation of this study is the multipath way analysis of cancer risk (CR) by oral ingestion, dermal absorption, and inhalation routes. In response to the increasing public concern on the pollution of the water supply, this study aims to estimate the THM exposure, lifetime CR caused by these different routes due to the use of tap water in the Cairo, Egypt. Cairo is located in middle of Egypt and has a variation of temperature during the whole of the year. The temperature ranges from $15^{\circ} \mathrm{C}$ in winter to $40^{\circ} \mathrm{C}$ in summer.

\section{Material and Methods}

Water samples analyzed according to (USEPA, 2005). The water samples were collected from five water treatment plants and its distribution systems, Water samples at the specified locations were collected in $40 \mathrm{ml}$ glass bottles (amber glass), which were filled without passing air bubbles through the sample. Before sampling, a solution of sodium thiosulfate was added to the amber bottles to eliminate any remaining residual chlorine and to stop further THM formation. Each glassware used was previously washed with phosphate-free detergent, rinsed with ultrapure water (Milli-Q) and acetone (HPLC grade). Then, it was placed in an oven at $150^{\circ} \mathrm{C}$ for $2 \mathrm{~h}$ and cooled at room temperature.

Samples were prepared by extracting $10 \mathrm{ml}$ of water with $2 \mathrm{ml}$ of pentane by shaking for $2 \mathrm{~min}$ in a separation funnel of $25 \mathrm{ml}$. Phase separation occurred within $3 \mathrm{~min}$ and the upper phase was collected into $2 \mathrm{ml}$ vials having screw caps with PTFE (Teflon septum) septa. THM measurements were made using a gas chromatograph equipped with a mass detector (GC-ECD, Varian, Model CP-3800). Chromatographic separation was accomplished with a capillary column DB-5 (J\&W Scientific Inc/Agilent Technologies, $30 \mathrm{~m} \times 0.25 \mathrm{~mm} \times 0.25 \mu \mathrm{m}$ ). The GC oven temperature program was as follow: initial temperature in $40^{\circ} \mathrm{C}$

*Corresponding author: Mahmoud A Khabeer, Holding Company for water and wastewater, Egypt, Tel: 01063232029; E-mail: abdelkhabeerm@yahoo.com

Received September 12, 2014; Accepted Septemebr 25, 2014; Published September 27, 2014

Citation: Souaya ER, Abdullah AM, RMaatook GA, Abdelkhabeer MA (2014) Exposure Assessment and the Risk Associated with Trihalomethane Compounds in Drinking Water, Cairo-Egypt . J Environ Anal Toxicol 5: 243. doi: 10.4172/2161-0525.1000243

Copyright: (c) 2014 Souaya ER, et al. This is an open-access article distributed under the terms of the Creative Commons Attribution License, which permits unrestricted use, distribution, and reproduction in any medium, provided the original author and source are credited. 
Citation: Souaya ER, Abdullah AM, RMaatook GA, Abdelkhabeer MA (2014) Exposure Assessment and the Risk Associated with Trihalomethane Compounds in Drinking Water, Cairo-Egypt . J Environ Anal Toxicol 5: 243. doi: 10.4172/2161-0525.1000243

Page 2 of 5

for 2 min and then ramped $10^{\circ} \mathrm{C}$ per min until $150^{\circ} \mathrm{C}$. Carrier gas $\left(\mathrm{N}_{2}\right)$ at a flow rate of $0.8 \mathrm{ml} \mathrm{min}^{-1}$ and split ratio of 1:10 was used in each experiment. It was injected $2 \mu \mathrm{l}$ of each sample in the capillary column. For the calibration curve, standard solutions of $\mathrm{CHCl}_{3}$ (Supelco Inc., 98.8\%), $\mathrm{CHBrCl}_{2}$ (Supelco Inc., 99.9\%), $\mathrm{CHBr}_{2} \mathrm{Cl}$ (Supelco Inc., 99.0\%), and $\mathrm{CHBr}_{3}$ (Supelco Inc., 99.9\%) in concentrations ranging from 0.05 to $100 \mu \mathrm{gL}^{-1}$ in ultrapure water.

The estimate of the lifetime CR associated to THM is based on United States Environment Protection Agency (USEPA) guidelines. The detailed description is presented in the literature (US EPA 1999), and it is not reproduced here. Three kinds of THM exposure were considered to estimate the lifetime CR: inhalation, dermal absorption and ingestion. The CR of THM is estimated by multiplying the chronic daily exposures (CDE) and a potency factor (upper-bound lifetime cancer risk per $\left.\mathrm{mg} \mathrm{kg}^{-1} \mathrm{day}^{-1}\right)$. The CDE for oral ingestion, dermal absorption and inhalation from volatilized water are respectively:

$$
\begin{aligned}
& C D E_{\text {ingestion }}=\frac{(C W \times I R \times E F \times E D)}{(B W \times A T L \times N Y)} \\
& C D E_{\text {dermal }}=\frac{(C W \times S A \times P C \times E T \times E F \times E D)}{(B W \times A T L \times N Y)} \\
& C D E_{\text {inhalation }}=\frac{(C A \times I R \times E T \times E F \times E D)}{(B W \times A T L \times N Y)}
\end{aligned}
$$

Where IR the ingestion rate $\left(\mathrm{L} \mathrm{day}^{-1}\right), \mathrm{EF}$ the exposure frequency (days year $^{-1}$ ), ED the exposure duration (years), BW the body weight $(\mathrm{kg})$, and ATL the average time of a lifetime (years), NY the number of days per year ( 365 days year $^{-1}$ ), SA the skin-surface area available for contact $\left(\mathrm{cm}^{2}\right)$, PC the chemical specific dermal permeability constant $\left(0.0020 \mathrm{mh}^{-1}\right)$, ET the exposure time, hour per day or hour per event $\left(0.2 \mathrm{~h} \mathrm{day}^{-1}\right)$, and IR the inhalation rate $\left(0.83 \mathrm{~m}^{3} \mathrm{~h}^{-1}\right)$.

The standard values of average body weight, volume of air breathed by adults per day, skin-surface area, and potency factor for oral ingestion and inhalation of THM are taken from the literature (US EPA 1999). For adults, the exposures were converted to a daily dose by assuming $20 \mathrm{~m}^{3}$ aspirated air per day, and average body weights of 70 $\mathrm{kg}$ for male and $65 \mathrm{~kg}$ for female. The lifetime of residents was assumed to be the standard 70 years for both male and female. Finally, the skinsurface areas are 1.94 and $1.69 \mathrm{~m}^{2}$ for males and females, respectively.

$$
\begin{aligned}
& \text { Weight of Population, } C=\frac{C_{i} \times P_{i}}{P_{\text {total }}} \\
& \text { Exposure pathway of Ingestion, } C D I=\frac{(C W \times 0.8 \times I R \times E F \times E D)}{(A T \times B W)}
\end{aligned}
$$

(Table 1)

\section{Results and Discussion \\ Chloroform $\left(\mathrm{CHCl}_{3}\right)$}

The data presented in Table 2 and Figure 1, showed that, the concentration of chloroform (Cai) ranged from 18.9 to $76.24 \mu \mathrm{g} / \mathrm{L}$ with average value $24.28 \mu \mathrm{g} / \mathrm{L}$ in Tebeen WTP, and the risk assessment of chloroform (HIi) ranged from $24.50 \mathrm{E}-6$ to $95.60 \mathrm{E}-6$ with average value 44.70E-6.

The concentration of chloroform (Cai) in Manial el roda WTP, ranged from 18.6 to $38.84 \mu \mathrm{g} / \mathrm{L}$ with average value $25.5 \mu \mathrm{g} / \mathrm{L}$, and the risk assessment of chloroform (HIi) ranged from 23.30E-6 to $48.70 \mathrm{E}-6$ with average value $32.00 \mathrm{E}-6$.

The concentration of chloroform (Cai) in Ameria WTP, ranged from 22.9 to $74.28 \mu \mathrm{g} / \mathrm{L}$ with average value $33.4 \mu \mathrm{g} / \mathrm{L}$, and the risk assessment of chloroform (HIi) ranged from 28.70E-6 to $93.10 \mathrm{E}-6$ with average value $41.90 \mathrm{E}-6$

The concentration of chloroform (Cai) in Shubra el kheima WTP ranged from 12.8 to $54.5 \mu \mathrm{g} / \mathrm{L}$ with average value $34.42 \mu \mathrm{g} / \mathrm{L}$, and the risk assessment of chloroform (HIi) ranged from 16.10E-6 to $68.30 \mathrm{E}-6$ with average value $43.20 \mathrm{E}-6$

The concentration of chloroform (Cai) in Embaba WTP, ranged from 21.4 to $53.4 \mu \mathrm{g} / \mathrm{L}$ with average value $39.69 \mu \mathrm{g} / \mathrm{L}$, and the risk assessment of chloroform (HIi) ranged from $26.8 \mathrm{E}-6$ to $67.00 \mathrm{E}-6$ with average value $49.80 \mathrm{E}-6$

\section{Bromodichloromethane $\left(\mathrm{CHBrCl}_{2}\right)$}

The data presented in Table 3 and Figure 2, showed that, the concentration of bromodichloromethane (Cai) ranged from 11.7 to $23.9 \mu \mathrm{g} / \mathrm{L}$ with average value $17.0 \mu \mathrm{g} / \mathrm{L}$ in Tebeen WTP, and the risk assessment of bromodichloromethane (HIi) ranged from $1.94 \times 10^{-5}$ to $3.96 \times 10^{-5}$ with average value $2.81 \times 10^{-5}$.

The concentration of bromodichloromethane (Cai) in RodaWTP, ranged from 10.63 to $16.47 \mu \mathrm{g} / \mathrm{L}$ with average value $14.0 \mu \mathrm{g} / \mathrm{L}$, and the risk assessment of bromodichloromethane (HIi) ranged from $1.76 \times 10$ ${ }^{5}$ to $2.72 \times 10^{-5}$ with average value $2.3 \times 10^{-5}$.

The concentration of bromodichloromethane (Cai) in Ameria WTP, ranged from 22.9 to $74.28 \mu \mathrm{g} / \mathrm{L}$ with average value $33.4 \mu \mathrm{g} / \mathrm{L}$, and the risk assessment of bromodichloromethane (HIi) ranged from $1.3 \times 10^{-5}$ to $4.2 \times 10^{-5}$ with average value $1.9 \times 10^{-5}$.

The concentration of bromodichloromethane (Cai) in Shubra el kheima WTP, ranged from 4.27 to $19.53 \mu \mathrm{g} / \mathrm{L}$ with average value 14.2 $\mu \mathrm{g} / \mathrm{L}$, and the risk assessment of bromodichloromethane (HIi) ranged from $7.1 \times 10^{-7}$ to $3.23 \times 10^{-5}$ with average value $2.35 \times 10^{-5}$.

The concentration of bromodichloromethane (Cai) in Embaba WTP, ranged from 13.6 to $23.4 \mu \mathrm{g} / \mathrm{L}$ with average value $19.24 \mu \mathrm{g} / \mathrm{L}$,

\begin{tabular}{|c|c|}
\hline Parameters & Value \\
\hline \multicolumn{2}{|l|}{$C_{i}:$ Concentration of i region } \\
\hline \multicolumn{2}{|c|}{$\mathrm{P}_{\mathrm{i}}$ : Population of water supply in the $\mathrm{i}$ region } \\
\hline \multicolumn{2}{|c|}{$\begin{array}{l}\mathrm{P}_{\text {Total }} \text { : Total population of water supply in the } \\
\text { i region }\end{array}$} \\
\hline \multicolumn{2}{|c|}{ Chronic daily intake, CDI (mg (Kg-day) $\left.)^{-1}\right)$} \\
\hline \multicolumn{2}{|c|}{ THMS concentration of drinking water, CE } \\
\hline Intake quantity, IR & 2.5 (litres day $^{-1}$ ) \\
\hline Average exposure time, AT & 70 (year) $\times 365$ (day/year) \\
\hline Exposure during, ED & 70 (Year) \\
\hline Exposure frequency, EF & 365 (day/year) \\
\hline \multirow[t]{2}{*}{ Body weight, BW } & Male : $64.8 \pm 10(\mathrm{Kg})$ \\
\hline & Female : $56.3 \pm 9.09(\mathrm{Kg})$ \\
\hline Absorptivity of body & $100 \%$ \\
\hline
\end{tabular}
and the risk assessment of bromodichloromethane (HIi) ranged from $2.25 \times 10^{-5}$ to $3.87 \times 10^{-5}$ with average value $3.18 \times 10^{-5}$.

\section{Chlorodibromomethane ( $\mathrm{CHBr} 2 \mathrm{Cl})$}

The data presented in Table 4 and Figure 3, showed that, the

Table 1: References data and formula for exposure assessment (USEPA, 2003) [8]. 


\begin{tabular}{|c|c|c|c|c|c|c|c|c|c|c|}
\hline \multirow{2}{*}{ Date } & \multicolumn{2}{|c|}{ Tebeen } & \multicolumn{2}{|c|}{ Roda } & \multicolumn{2}{|c|}{ Ameria } & \multicolumn{2}{|c|}{ Shubra el kheima } & \multicolumn{2}{|c|}{ Embaba } \\
\hline & Cai & Hli & Cai & HIi & Cai & HIi & Cai & HIi & Cai & $\mathrm{Hli}$ \\
\hline Jan & 0.015 & $25.5 \mathrm{E}-6$ & 0.014 & 22.7E-6 & 0.017 & $28.0 \mathrm{E}-6$ & 0.017 & 27.9E-6 & 0.015 & $24.8 \mathrm{E}-6$ \\
\hline Feb & 0.020 & $32.7 \mathrm{E}-6$ & 0.015 & 24.9E-6 & 0.016 & 25.7E-6 & 0.015 & 24.9E-6 & 0.019 & $31.2 \mathrm{E}-6$ \\
\hline Mar & 0.018 & $30.1 \mathrm{E}-6$ & 0.011 & 17.6E-6 & 0.015 & 24.1E-6 & 0.013 & 21.3E-6 & 0.016 & $27.0 \mathrm{E}-6$ \\
\hline Apr & 0.016 & $26.2 \mathrm{E}-6$ & 0.011 & 18.2E-6 & 0.014 & $23.4 \mathrm{E}-6$ & 0.014 & 23.9E-6 & 0.022 & $36.0 \mathrm{E}-6$ \\
\hline May & 0.017 & $27.4 \mathrm{E}-6$ & 0.014 & 23.1E-6 & 0.016 & 25.9E-6 & 0.004 & 7.1E-6 & 0.023 & $38.2 \mathrm{E}-6$ \\
\hline Jun & 0.015 & $25.2 \mathrm{E}-6$ & 0.015 & 24.2E-6 & 0.010 & 16.3E-6 & 0.009 & 14.2E-6 & 0.018 & 29.6E-6 \\
\hline Jul & 0.016 & 26.6E-6 & 0.015 & $24.4 \mathrm{E}-6$ & 0.016 & $26.2 \mathrm{E}-6$ & 0.016 & $26.8 \mathrm{E}-6$ & 0.019 & 31.7E-6 \\
\hline Aug & 0.018 & $30.0 \mathrm{E}-6$ & 0.016 & 25.7E-6 & 0.019 & $30.6 \mathrm{E}-6$ & 0.017 & $27.8 \mathrm{E}-6$ & 0.021 & $34.4 \mathrm{E}-6$ \\
\hline Sep & 0.024 & $39.6 \mathrm{E}-6$ & 0.014 & 22.9E-6 & 0.021 & 34.7E-6 & 0.018 & 29.5E-6 & 0.023 & $37.4 \mathrm{E}-6$ \\
\hline Oct & 0.015 & 24.1E-6 & 0.016 & 27.2E-6 & 0.019 & 31.0E-6 & 0.020 & 32.3E-6 & 0.023 & 38.7E-6 \\
\hline Nov & 0.019 & $30.7 \mathrm{E}-6$ & 0.015 & $25.5 \mathrm{E}-6$ & 0.017 & $28.4 \mathrm{E}-6$ & 0.016 & 27.2E-6 & 0.018 & $30.3 E-6$ \\
\hline Dec & 0.012 & 19.4E-6 & 0.013 & 21.3E-6 & 0.015 & 24.3E-6 & 0.011 & 19.0E-6 & 0.014 & $22.5 \mathrm{E}-6$ \\
\hline
\end{tabular}

Table 2: Risk assessment of Bromodichloromethane.

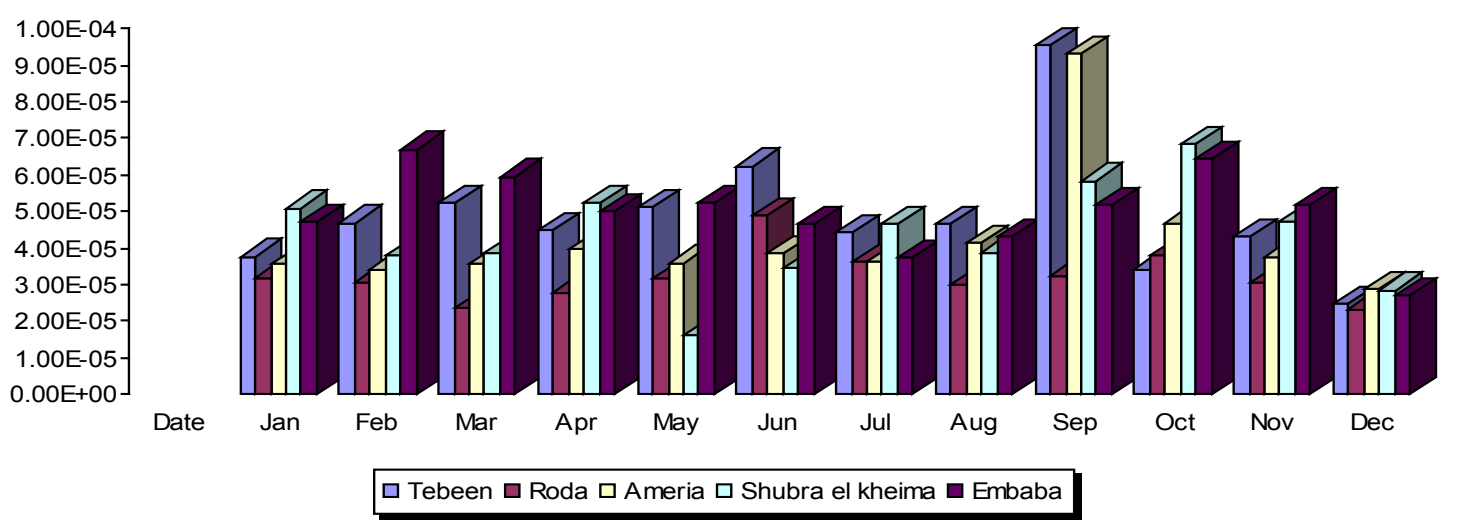

Figure 1: Chloroform risk assessment in the outlets of the water treatment plants.

\begin{tabular}{|c|c|c|c|c|c|c|c|c|c|c|}
\hline \multirow{2}{*}{ Date } & \multicolumn{2}{|c|}{ Tebeen } & \multicolumn{2}{|c|}{ Roda } & \multicolumn{2}{c|}{ Ameria } & \multicolumn{2}{c|}{ Shubra el kheima } & \multicolumn{2}{c|}{ Embaba } \\
\cline { 2 - 12 } & Cai & Hli & Cai & Hli & Cai & Hli & Cai & Hli & Cai & Hli \\
\hline Jan & 15.41 & $25.5 \mathrm{E}-6$ & 13.716 & $22.7 \mathrm{E}-6$ & 16.939 & $28.0 \mathrm{E}-6$ & 16.89 & $27.9 \mathrm{E}-6$ & 14.999 & $24.8 \mathrm{E}-6$ \\
\hline Feb & 19.771 & $32.7 \mathrm{E}-6$ & 15.089 & $24.9 \mathrm{E}-6$ & 15.534 & $25.7 \mathrm{E}-6$ & 15.08 & $24.9 \mathrm{E}-6$ & 18.854 & $31.2 \mathrm{E}-6$ \\
\hline Mar & 18.188 & $30.1 \mathrm{E}-6$ & 10.631 & $17.6 \mathrm{E}-6$ & 14.552 & $24.1 \mathrm{E}-6$ & 12.903 & $21.3 \mathrm{E}-6$ & 16.344 & $27.0 \mathrm{E}-6$ \\
\hline Apr & 15.832 & $26.2 \mathrm{E}-6$ & 11.033 & $18.2 \mathrm{E}-6$ & 14.175 & $23.4 \mathrm{E}-6$ & 14.433 & $23.9 \mathrm{E}-6$ & 21.8 & $36.0 \mathrm{E}-6$ \\
\hline May & 16.6 & $27.4 \mathrm{E}-6$ & 13.991 & $23.1 \mathrm{E}-6$ & 15.684 & $25.9 \mathrm{E}-6$ & 4.277 & $7.1 \mathrm{E}-6$ & 23.1 & $38.2 \mathrm{E}-6$ \\
\hline Jun & 15.232 & $25.2 \mathrm{E}-6$ & 14.655 & $24.2 \mathrm{E}-6$ & 9.832 & $16.3 \mathrm{E}-6$ & 8.566 & $14.2 \mathrm{E}-6$ & 17.9 & $29.6 \mathrm{E}-6$ \\
\hline Jul & 16.115 & $26.6 \mathrm{E}-6$ & 14.781 & $24.4 \mathrm{E}-6$ & 15.824 & $26.2 \mathrm{E}-6$ & 16.206 & $26.8 \mathrm{E}-6$ & 19.2 & $31.7 \mathrm{E}-6$ \\
\hline Aug & 18.147 & $30.0 \mathrm{E}-6$ & 15.516 & $25.7 \mathrm{E}-6$ & 18.522 & $30.6 \mathrm{E}-6$ & 16.832 & $27.8 \mathrm{E}-6$ & 20.8 & $34.4 \mathrm{E}-6$ \\
\hline Sep & 23.962 & $39.6 \mathrm{E}-6$ & 13.846 & $22.9 \mathrm{E}-6$ & 20.978 & $34.7 \mathrm{E}-6$ & 17.871 & $29.5 \mathrm{E}-6$ & 22.6 & $37.4 \mathrm{E}-6$ \\
\hline Oct & 14.591 & $24.1 \mathrm{E}-6$ & 16.475 & $27.2 \mathrm{E}-6$ & 18.754 & $31.0 \mathrm{E}-6$ & 19.532 & $32.3 \mathrm{E}-6$ & 23.4 & $38.7 \mathrm{E}-6$ \\
\hline Nov & 18.559 & $30.7 \mathrm{E}-6$ & 15.405 & $25.5 \mathrm{E}-6$ & 17.173 & $28.4 \mathrm{E}-6$ & 16.434 & $27.2 \mathrm{E}-6$ & 18.3 & $30.3 \mathrm{E}-6$ \\
\hline Dec & 11.743 & $19.4 \mathrm{E}-6$ & 12.872 & $21.3 \mathrm{E}-6$ & 14.707 & $24.3 \mathrm{E}-6$ & 11.487 & $19.0 \mathrm{E}-6$ & 13.6 & $22.5 \mathrm{E}-6$ \\
\hline
\end{tabular}

Table 3: Risk assessment of bromodichloromethane.

concentration of Chlorodibromomethane (Cai) ranged from 4.32 to $8.58 \mu \mathrm{g} / \mathrm{L}$ with average value $6.52 \mu \mathrm{g} / \mathrm{L}$ in Tebeen WTP, and the risk assessment of Chlorodibromomethane (HIi) ranged from 0 to $1.92 \times 10$ ${ }^{5}$ with average value $8.5 \times 10^{-6}$.

The concentration of Chlorodibromomethane (Cai) in RodaWTP, ranged from 4.89 to $7.58 \mu \mathrm{g} / \mathrm{L}$ with average value $6.6 \mu \mathrm{g} / \mathrm{L}$, and the risk assessment of Chlorodibromomethane (HIi) ranged from 0 to $1.7 \times 10^{-5}$ with average value $7.4 \times 10^{-6}$.
The concentration of Chlorodibromomethane (Cai) in Ameria WTP, ranged from 4.48 to $7.8 \mu \mathrm{g} /$ Lwith average value $6.5 \mu \mathrm{g} / \mathrm{L}$, and the risk assessment of Chlorodibromomethane (HIi) ranged from 0to $1.76 \times 10^{-5}$ with average value $8.5 \times 10^{-6}$.

The concentration of Chlorodibromomethane (Cai) in Shubra el kheima WTP, ranged from 4.8 to $5.8 \mu \mathrm{g} / \mathrm{L}$ with average value $5.5 \mu \mathrm{g} / \mathrm{L}$, and the risk assessment of Chlorodibromomethane (HIi) ranged from 0to $1.3 \times 10^{-5}$ with average value $6.1 \times 10^{-6}$. 


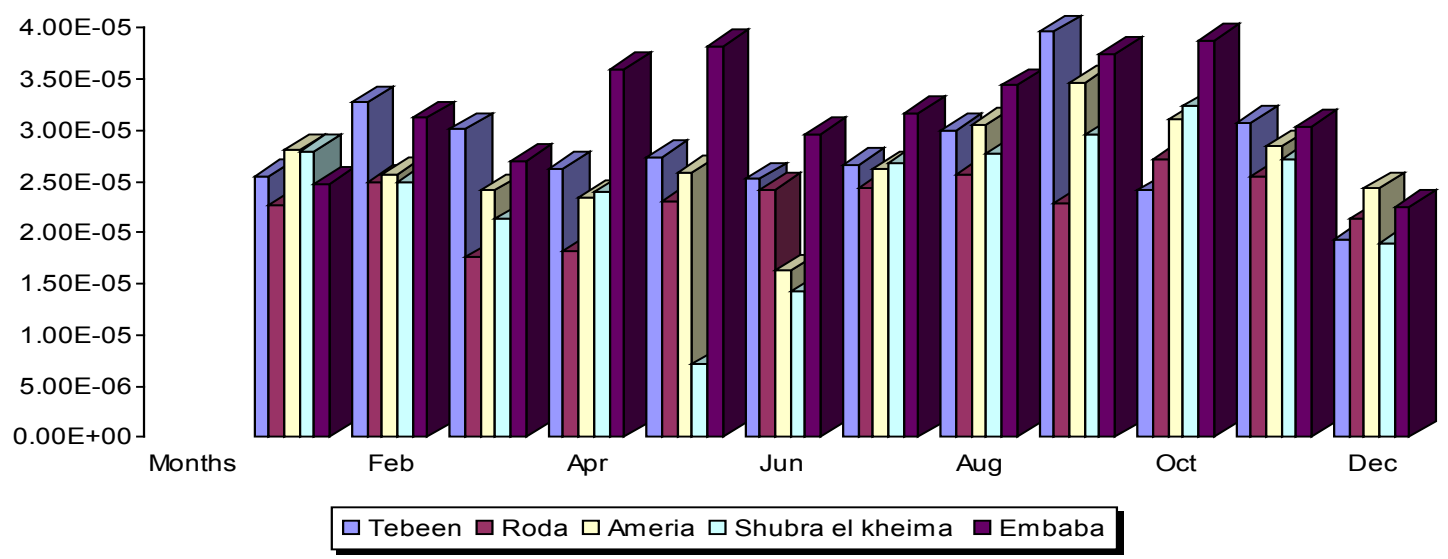

Figure 2: Bromodichloromethane risk assessment in the outlets of the water treatment plants.

\begin{tabular}{|c|c|c|c|c|c|c|c|c|c|c|}
\hline \multirow{2}{*}{ Date } & \multicolumn{2}{|c|}{ Tebeen } & \multicolumn{2}{|c|}{ Roda } & \multicolumn{2}{|c|}{ Ameria } & \multicolumn{2}{|c|}{ Shubra el kheima } & \multicolumn{2}{|c|}{ Embaba } \\
\hline & Cai & HIi & Cai & HIi & Cai & HIi & Cai & HIi & Cai & HIi \\
\hline Jan & 7.321 & 16.4E-6 & 6.49 & $14.5 \mathrm{E}-6$ & 7.861 & 17.6E-6 & 5.832 & $13.1 \mathrm{E}-6$ & 4.222 & $9.5 \mathrm{E}-6$ \\
\hline Feb & 7.389 & 16.6E-6 & 7.347 & 16.5E-6 & 6.468 & $14.5 \mathrm{E}-6$ & 5.565 & $12.5 \mathrm{E}-6$ & UDL & 0 \\
\hline Mar & 4.327 & 9.7E-6 & UDL & 0 & UDL & 0 & UDL & 0 & UDL & 0 \\
\hline Apr & UDL & 0 & UDL & 0 & UDL & 0 & UDL & 0 & UDL & 0 \\
\hline May & UDL & 0 & UDL & 0 & 4.483 & 10.0E-6 & UDL & 0 & 6.8 & $15.2 \mathrm{E}-6$ \\
\hline Jun & UDL & 0 & UDL & 0 & UDL & 0 & UDL & 0 & 5.2 & $11.6 \mathrm{E}-6$ \\
\hline Jul & UDL & 0 & UDL & 0 & UDL & 0 & UDL & 0 & UDL & 0 \\
\hline Aug & UDL & 0 & UDL & 0 & UDL & 0 & UDL & 0 & UDL & 0 \\
\hline Sep & 6.528 & 14.6E-6 & 4.897 & $11.0 \mathrm{E}-6$ & 5.126 & $11.5 \mathrm{E}-6$ & 4.881 & 10.9E-6 & UDL & 0 \\
\hline Oct & 6.115 & 13.7E-6 & 6.683 & 15.0E-6 & 7.084 & 15.9E-6 & 5.696 & $12.8 \mathrm{E}-6$ & 7.4 & 16.6E-6 \\
\hline Nov & 8.585 & 19.2E-6 & 7.587 & 17.0E-6 & 7.855 & 17.6E-6 & 5.696 & $12.8 \mathrm{E}-6$ & 7.4 & 16.6E-6 \\
\hline Dec & 5.417 & 12.1E-6 & 6.638 & 14.9E-6 & 6.926 & $15.5 \mathrm{E}-6$ & 5.221 & 11.7E-6 & 6.3 & 14.1E-6 \\
\hline
\end{tabular}

Table 4: Risk assessment of chlorodibromomethane.

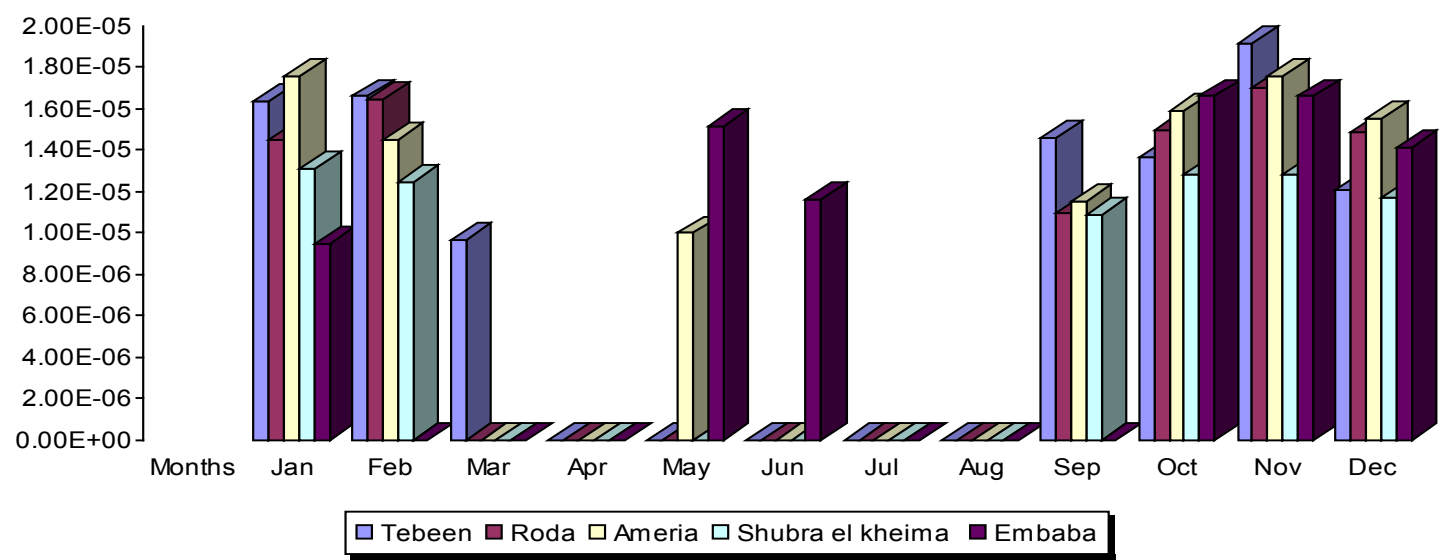

Figure 3: Bromodichloromethane risk assessment in the outlets of the water treatment plants.

The concentration of Chlorodibromomethane (Cai) in Embaba WTP, ranged from 4.2 to $7.4 \mu \mathrm{g} / \mathrm{L}$ with average value $6.2 \mu \mathrm{g} / \mathrm{L}$, and the risk assessment of Chlorodibromomethane (HIi) ranged from 0 to $1.66 \times 10^{-5}$ with average value $6.97 \times 10^{-6}$.

\section{Bromoform $\left(\mathrm{CHBr}_{3}\right)$}

In the present study, the collected samples from the water treatment plants (Tebeen, Roda, Ameria, Shoubra El Khema and Embaba WTPs) did not detect, so the risk assessment of bromoform were neglect.

For THM species, the USEPA range of concern is for an increased carcinogenic risk of $10^{-6}$, that is, $1: 1,000,000$ [8-10].

Total carcinogenic risks for each of the oral and dermal routes were calculated as the sum of the risks values for four THMs specie, that is, 
Total risk=risk for chloroform + risk for bromodichloromethane + risk for dibromochloromethane + risk for bromoform (RAIS).

Lifetime cancer risk value due to the oral ingestion of TTHMs in different districts of the Cairo city were exceeded from $1.0 \times 10^{-6}$, showing that residents of these districts were expected to be at higher cancer.

Risk hazard index for different districts was found to be lower than unity, indicating that no adverse health effects are expected as a result of exposure to THMs.

\section{Conclusion}

This investigation included statistical analysis, epidemiology data and cancer risk analysis and assessment of THMs species in drinking water in Cairo. It is more significant to establish an assessment procedure for the decision-making in policy of drinking water safety predominantly.

\section{Specification the derive conclusions lie above from this study:}

- The chloroform concentration is the major DBP species in the local regions of Cairo.

- The most dominant THMs are chloroform and bromodichloromethane and residents have a higher cancer risks through these two compounds in all results of studied five plants.

- Bromoform did not observed in most of collected samples.

- All lifetime cancer risks for $\mathrm{CHCl} 3, \mathrm{CHBrCl} 2$ and $\mathrm{CHBr} 2 \mathrm{Cl}$ in water samples collected from tap water in the five water supply areas were higher than the negligible risk level of $10-6$ by a factor of 10 or more in most districts.

- The Southern region presented a high cancer risk (Tebeen WTP).

- Residents of some districts were found to have a higher cancer risk through the oral ingestion of THMs. hazard indexes of TTHMs in different districts were found to be lower than unity, which did not indicate the noncancerous effects of THMs.

- Quantifying the risk factors is important for population and decision-making policy for drinking water safety. Fortunately, the Benchmark model and MCS and Risk supply the methodology were used for risk calculation. The standard for the total THMs species in Taiwan was $100 \mu \mathrm{g} / \mathrm{L}$ presently.
- We suggest that the standard be separated using separate dibromochloromethane, bromoform, chloroform, and bromodichloromethane standards. This may establish a control management for individual material to reduce the harmful risk. It displays the legislation limit values for different counties for DBPs levels.

- A methodology for decision-makers in formulating a procedure considering the economic, political, and feasible technology to reduce the standard value limits is necessary. An acceptable policy for safe drinking water and optimum social cost is the next objective of our study.

- The techniques can be used for removal of THM compounds are activated carbon, enhancement coagulation, alternatives of disinfectants such as ozone, chloramine and chlorine dioxide.

\section{References}

1. Chowdhury MJ, Rodriguez, Sadiq R (2011) Disinfection byproducts in Canadian provinces: associated cancer risks and medical expenses. J Hazard Mater 187 574-584.

2. Golfinopoulos SK, Kostopoulou MN, Lekkas TD (1996) THMs formation in the highbromide water supply of Athens. J Environ Sci Health A 31: 67-8.

3. Gallagher MD, Nuckols JR, Stallones L, Savitz DA (1998) Exposure to trihalomethanes and adverse pregnancy outcomes. Epidemiology 9: 484-489.

4. Hsu CH, Jeng WL, Chang RM, Chien LC, Han BC (2001) Estimation of potential lifetime cancer risks for trihalomethanes from consuming chlorinated drinking water in Taiwan. Environ Res 85: 77-82.

5. Gottlieb MS, Carr JK, Clarkson JR (1982) Drinking water and cancer in Louisiana. A retrospective mortality study. Am J Epidemiol 116: 652-667.

6. Hossein P, Stevens AA (1995) Relationship between trihalomethanes and haloacetic acids withtotal organic halogen during chlorination. Water Res 29: 2059-2062.

7. Rafael J, Garcia Villanova, Cesar Garcia, Alfonso Gomez J, Paz Garcia M et al. (199) Formation, Evaluation and Modeling Rats and B6C3F1 Mice (gavage studies). NationalToxicology Program Technical Report Series No. 350. DHHS Publications No. (NIH), 89-2805

8. USEPA (2003) Draft final guidelines for carcinogen risk assessment.

9. USEPA (2004) the Benchmark Dose Software 1.3.2.

10. USEPA. (2005): USEPA Drinking Water Methods for Chemical Contaminants Office of Ground Water and Drinking Water. EPA method 551. 